\title{
Püstijalakomöödia Eestis: estraadietendustest Comedy Estoniani ${ }^{1}$
}

\begin{abstract}
Liisi Laineste
Teesid: Artikkel kirjeldab nähtust, millel siiani puudub ühene kokkuleppeline eestikeelne nimetus ja mida ajakirjanduses nimetatakse stand-up komöödiaks või püstijalakomöödiaks. Vaatame, kuidas see meelelahutusžanr sobitub Eestis oma eelkäijate, peamiselt lavakomöödia ja estraadietenduste, ajaloolisse ja kultuurilisse konteksti. Põhirõhk on eelkõige aastatel 2010-2012, mil Comedy Estonia nime kandev rühmitus on aktiivselt korraldanud stand-up komöödia etteastetega pubiõhtuid, mille formaat järgib anglo-ameerika eeskuju. Artikli eesmärk on näidata, kuidas nii esineja- kui ka publikupoolsed ootused mõjutavad žanri üldist populaarsust ja staatust ühiskonnas. Artisti positsiooni lahkamisel on toeks Lawrence Mintzi (1985) termin "negatiivne isend" (negative exemplar), mis tähistab rõhutatult marginaalset lavategelast.

Peamiselt leiab käsitlust kaks perioodi Eesti lähiajaloos, nõukogude aeg ja tänapäev, ning stand-up või selle analoog mõlemas kontekstis. Nõukogude estraadietenduste traditsioon, aga ka komöödiapalade ettelugemine raadiosalvestustel (nt "Meelejahutaja"), oli äärmiselt hinnatud meelelahutus, mis pakkus pealtnäha süütul moel leevendust totalitaarse režiimi igapäevaelu absurdile. Kolme siiani kõige hinnatuma huumorisketši sisu sellest ajajärgust vaadeldakse analüüsiosas kõrvuti Comedy Estonia repertuaariga, et leida retseptsiooni ja staatuse erinevuste põhjuseid. Ka Comedy Estonial on pühendunud publik ja kindel teemavalik, kuid need erinevad oluliselt nõukogude estraadist. Taustsüsteeme arvesse võttes on võimalik kirjeldada erinevate traditsioonide kohandumist ja mugandamist kui identiteediloome osa, mille käigus võõras muutub omaks ja hakkab toimima rühmaühtsust kinnitava tegurina, olgu see siis terve rahvuse või väikese grupi tasandil.

Artikli empiiriline osa käsitleb materjali mõlemast perioodist, keskendudes peamiselt teemadele ja tegelastele, mis eri ajastute komöödiarepertuaaris sagedaimini ette tulevad.
\end{abstract}

Märksõnad: estraad, püstijalakomöödia ajalugu Eestis, retseptsioon, stand-up komöödia 


\section{Sissejuhatus}

Huumor on globaalne nähtus, kuid selle žanrilised väljendused võtavad rahvuseti ja kultuuriti erinevaid vorme. Stand-upi ajalugu ulatub 19. sajandi ameerika vodevillini ja briti revüüteatrini (sageli mainitakse selles kontekstis ka Mark Twaini koomilisi loenguid aastast 1856; Stebbins 1990: 7), kui siinkohal mitte arvestada koomilise esinemise iidseid juuri rahvakultuuris. Stand-up pole kaugeltki isoleeritud žanr, see tekib ja areneb vastavalt auditooriumi vajadustele ja soovidele, omades eri perioodidel ja keskkondades erinevaid varjundeid. Seetõttu peaks kohaliku stand-up kultuuri kirjeldamisel alati arvesse võtma eelkäijaid, välismõjutusi ja kohalikku olustikku, mis kujundavad žanri sisu ja piire.

Internetiajastu algus on lihtsustanud ligipääsu huumoritekstidele ja etteastetele, mida enne tunti vaid kohaliku keele- või kultuuriruumi piires. Just nooremal põlvkonnal on huvi ja võimalus tutvuda arvukate ingliskeelsete stand-upi ajalugu ja tänapäeva illustreerivate videotega YouTube'i või teiste veebiallikate vahendusel. Internet saab sageli žanriga tutvumise lähtepunktiks, sest nende videote põhjal tekib globaalsel stand-up huviliste kogukonnal ettekujutus, mida tuleks oodata kohalikul pubiõhtul, kuhu on kutsutud esinema stand-up koomikud. Et see ettekujutus põhineb eelkõige anglo-ameerika eeskujudel, mõjutab varasem kokkupuude žanriga tugevalt potentsiaalse auditooriumi suhtumist lavale toodud teemadesse ning seega ka artistide edasist repertuaarivalikut.

Kuigi kultuurid ja kontekstid on erinevad, kehtib stand-up koomiku definitsioon võrdselt ja kultuuriüleselt: stand-up koomik on kultuurimediaator ja antropoloog (Mintz 1985: 73; Koziski 1997). Stand-up laval jutustab koomik oma kogemustest ja kokkupuudetest ümbritseva sotsiaalse reaalsusega, ja loob seda tehes võimaluse koos kuulajaskonnaga suunata või rõhutada väljendamist vajavaid tundeid (Purcell jt 2010: 377). Mõningatel juhtudel võib humoorikas tekst saada jagatud kultuurimälu osaks, mida selle kogukonna liikmed tsiteerivad veel aastakümneid hiljem. Veelgi harvem võib juhtuda, et aktiivset positiivset vastukaja saanud tekst levib ka väljapoole algset auditooriumi. Siis on enamasti tegu teemadega, millel on globaalne haare: 11. septembri sündmused USAs, Muhammedi karikatuurid Taanis ning sellele järgnenud rahutused jms. Nende sündmuste ülemaailmne kajastamine komöödiaetteastetes näitab, et olulised globaalsed teemad on stand-upi lavale teretulnud, sest see on tähtis osa tänapäeva maailmast. Samas võib sama teemat lahendada mitmel moel. Kui esineja vaatenurk on kuulajatele võõras või hirmutav, siis nali äpardub ning tulemus võib olla ettearvamatu. Mida suurem on publik, seda suurem on ka tõenäosus, et kuulajate hulgas leidub inimesi, kes tunnevad end artisti märkustest puudutatuna. Püstijalakomöödia algses loomuses on olla terav, päevakajaline ja agressiivne, mistôttu on peaaegu võimatu globaalselt jälgi- 
taval laval (nt internetis rippuvas stand-up videos) kommenteerida mõnda olulist teemat, riskimata publiku solvamisega. Komöödiaartist peab valdama kohandumise peent kunsti, tunnetades juba esimeste ridadega, millised on konkreetse publiku eelistused, mis teemad neid ei huvita ja, mis kõige olulisem, milliseid teemasid tuleks arusaamatuste ärahoidmiseks vältida. Eriti selgelt väljendub see multikultuursetes ühiskondades; näiteks Muhammedi karikatuuride avaldamise algseks eesmärgiks oli anda sallivuse õppetund Taanis elavatele moslemitele, mis aga ebaõnnestus, sest suur osa auditooriumist ei suutnud hinnata ettevõtmise huumorit ega tabada ka üldisemat, "harivat" sõnumit. Stand-up esineja paindlikkus ja oskus kõnetada konkreetset publikut konkreetsel õhtul määrab suures osas tema populaarsuse. Ilma paindlikkuseta nii sisus kui vormis kaotab esineja kontakti publikuga.

Lawrence Mintz (1985) kasutab stand-up artisti iseloomustamiseks "negatiivse isendi" terminit. Esineja marginaalsus tagab loa puudutada teemasid, mida tegelikkuses ei tohiks rünnata, naerualuseks teha või üldse nimetadagi. Esinejale on seega antud "koomiku luba" (comic license, ibid.). Negatiivse isendi kuvandit iseloomustab esineja marginaalsus antud ühiskonnas ja konkreetse publiku ees. Selle mõiste abil on võimalik avada nii estraaditähtede kui ka Comedy Estonia artistide tegelaskujusid, sest enamasti kuuluvad need just äärealasse, eluheidikutest võimuladvikuni, jättes vahele tavalise inimese, kelle elu nad marginaalselt positsioonilt läbi huumoriprisma jälgivad. Stigmatiseeritud tegelastel on igapäevaelu pahupoole üle naermine lihtsam, sest valusa kriitika autoriks pole sel juhul keegi siseringist, vaid võõras, kes on nalja objektiga piisavalt sarnane ja tuttav, kuid samas sellest distantseerunud.

Sarnased huvid ja huumorieelistused võivad olla eelduseks sellele, et publik võtaks omaks stand-up artisti stiili (kui tal on püsiv lavaroll, siis ka selle). Kuid käsitletavatest teemadest olulisemaks võivad osutuda esineja isiksus ja energia, mis tekib esineja suhtlemisel publikuga.

Käesolev artikkel seab eesmärgiks analüüsida tegureid, mis mõjutavad žanri populaarsust erinevatel ajastutel, käsitledes konkreetseid teemasid esinemiskontekstis ja laiemat kultuurilist tausta. Vaatluse all on ka esineja rollimuutused ja -kohandused, mis on tingitud publiku huvidest. Peamiselt leiab käsitlust kaks perioodi Eesti lähiajaloos, nõukogude aeg ja tänapäev, ning stand-up või selle analoog mõlemas kontekstis. Nende kahe perioodi komöödialava seob asjaolu, et mõlemal juhul on kohalikku praktikasse integreeritud tugevaid välismõjusid; esimesel juhul nõukogude vennasvabariikide estraadirepertuaar ja teisel juhul anglo-ameerika eeskujud. Kuigi mõlemal perioodil on selged välised mõjutajad, erineb nende kohandamine ja sellest tulenevalt ka staatus ühiskonnas ning populaarsuse tase. Uurimuse fookuseks on traditsioonide ja tekstide tähenduslik adapteerimine, mille tulemusel võõras muutub omaks ja hakkab toimima kollektiivse identiteedi osana - olgu see kollektiiv terve rahvus või ainult väike osa sellest. 
Kõigepealt kirjeldatakse eesti koomilise lavaliste etteastete kultuurilist tausta, põhirõhuga nõukogude estraadil, et luua ülevaade põhjast, millele Comedy Estonia ehitab oma traditsiooni. Artikli empiiriline osa käsitleb materjali mõlemast perioodist, keskendudes peamiselt teemadele ja tegelastele, mis eri ajastute komöödiarepertuaaris sagedaimini ette tulevad.

\section{Taust}

Eesti huumorit on läbi aegade mõjutanud kokkupuuted teiste rahvustega. Loomulikult ei teki mistahes pärimus isolatsioonis, vaid on pidevas muutuses sõltuvalt sellest, mida (lavalt) välja pakutakse ja mida on publik valmis sellest omaks võtma.Varased mõjutused jõudsid stand-up žanrisse Balti-Saksa kanaleid kaudu; vaatamata kuulumisele Vene impeeriumisse säilitas Eestis tugeva positsiooni baltisaksa aadel. Kuigi varane stand-up ei olnud poliitiliselt terav nagu saksa kabareekultuur (Jelavich 1996: 10), laenas see siiski viimaselt mõningaid elemente. Muuhulgas tegutses Eestis Saksa rahvuslik komöödiateatriliikumine "Puhkus ja elurõõm" (Kraft durch Freude). Esimese maailmasõja eelse näitelava vallutasid amatööridest lavastajad ja näitlejad, kelle sagedane valik oli just komöödia, seda nii grupi kui ka sooloesinemistes. Tekkisid esimesed rändnäitlejad, kes keskendusid komöödiažanrile, esinedes järjest mitmetes linnades või astudes üles koos teiste esinejatega, nt laulunumbrite vahel (sajandivahetuse lehtedes on hulgaliselt kuulutusi selliste kabareeõhtute kohta, kus esitati vaheldumisi mitmeid meelelahutusžanreid). Mõned avaldasid oma repertuaari ka trükituna (nt Trilljärv 1919), mis näitab, et nii publik kui ka algajad amatöörnäitlejad oli žanrist huvitatud.

Esimesed iseseisvumisjärgsed aastad 20. sajandi esimesel poolel olid tunnistajaks professionaalse teatri sünnile Eestis, ning 1938. aastal avati Tallinna Konservatooriumi juures riiklik lavakunstikool. Ühest küljest tähendas see seda, et näitlejad püüdlesid "tõsisema” repertuaari mängimise poole, kuid samal ajal ei vähenenud publiku huvi komöödia vastu.

Järgmise perioodi telje moodustab nõukogude estraadižanr, mis jõudis Eestisse 1960. aastatel ja mille populaarsus tõusis kuni nõukogude aja lõpuni. Estraadi ingliskeelseks vasteks huumori-alases kirjanduses on enamasti varietee, mis pakub erinevaid meelelahutuslikke numbreid nii muusika, tantsu kui ka näitlemise vallast (Mesropova 2008). Algselt aga tähendas hispaaniakeelne mõiste estrado (lit 'väike lava') klassikalisele teatrirepertuaarile vastanduvat alternatiivset lavaetendust. Estraadikava paralleelid anglo-ameerika standupiga väljenduvad selle isikukesksuses, kohalolekus ja interaktsioonis publikuga (kolm stand-upi põhiaspekti Oliver Double’i kirjelduses; Double 2005: 19). 
1990. aastail estraadi mõiste kadus, samal ajal otsisid juba varem tunnustatud komöödianäitlejad esinemiseks teisi formaate. Taasiseseisvumise järel said hoo sisse humoorikad ülesastumised suvistel kontserttuuridel: ansambel Kuldne Trio esitas poliitilist satiiri sisaldavat laulurepertuaari ja kupleesid, Vana Baskini teater etendas omaloomingulisi lavakomöödiaid (nt etendus "Prügikast"), raadios kogus populaarsust absurdihuumori poolest silma paistnud Kreisiraadio, televaatajaile pakuti paroodiaga vürstitatud meelelahutust (nt Henrik Normann) jmt. Samal ajal polnud Eestis veel märki läänes levinud stand-upist, kus esinejad astuvad oma lugudega lavale ja räägivad, publikuga samal ajal suheldes ja nalju nende reaktsioonile vastavalt ritta seades, oma kogemustest ja vaadetest. Nagu eelnevast näha, asendasid estraadi mitmed omavahel üsna lõdvalt seotud komöödialiigid, ja esialgu tundus, et ennustus huumori kadumisest pärast nõukogude režiimi langemist on õigustatud (vt ka Mesropova 2008). Aastal 2010 märkasid seda tühimikku mõned Eestis elavad välismaalased, kes rääkisid sel teemal Soomes tegutsenud rühmituse Comedy Finland liikme, austraallase Louis Zezeraniga. Samal aastal loodud Comedy Estonia tuumiku moodustasid mõned Ameerikast ja Austraaliast Eestisse tulnud komöödiasõbrad, kes võtsid omale eesmärgiks tutvustada eesti publikule standupi. Antud intervjuudes on Comedy Estonia liikmed tunnistanud, et kuigi nad on teadlikud estraadikomöödiast ja näevad seda kui ühe-mehe-teatrit (one man theatre), ei arva nad, et see on stand-upi otsene eelkäija Eestis - vähemalt mitte briti või ameerika mõttes (intervjuu Louis Zezeraniga, 22. veebruaril 2012). Nende eeskujul on ka teised tajunud ära vaba koha komöödiamaastikul ning pakkunud publikule nii eesti- kui ingliskeelset stand-upi, nt teatritudengite Kinoteater, Von Krahli klubis stand-up õhtuid korraldanud Komeediklubi, või YouTube’i kanal MiinusMiljon.

\section{Estraad ja stand-up: ühisosa}

Oliver Double (2005: 19), kes on praktiku vaatepunktist stand-up komöödiat analüüsinud, defineerib kõnealust žanri kolme põhilise tunnuse kaudu. Peale selle, et stand-up artisti eesmärgiks on publikut lõbustada, paneb esinemisele kõigepealt aluse esineja isiksus. Esineja astub publiku ette üksi, ja ainuke vahend, mis tal koomilise efekti tekitamiseks on, on tema ise: tema hääl, liigutused ja tekst. Esineja võib kehastada ajutiselt mõnda karakterit ja liikuda erinevate karakterite vahel või kasutada pidevalt samasugust lavaisiksust, ta võib ka esineda iseendana, kuid tema isiksus on esimene ja ainuke asi, mida publik laval näeb. Teiseks defineerivaks tingimuseks on laval seisva isiksuse ja publiku vahel toimuv otsene kommunikatsioon, mis ei pea olema alati ver- 
baalne: Double rõhutab eraldi olulise suhtluskanalina osapoolte vahel tekkivat energiavälja. Laval seisja räägib ja publik vastab sellele naeru, vaikimise või pahameelehüüatustega. Kolmanda tingimusena mainib ta hetke, milles esinemine toimub. Stand-up leiab aset siin ja praegu ning esineja peab reageerima sellele, mis esinemise ajal tema ümber toimub. Publiku usaldust ja esineja staatust vähendab oskamatus keerata enda kasuks publiku kommentaare, segavat telefonihelinat või hilinenud/lahkuvaid kuulajaid.

Neid tingimusi täitis mõningate mööndustega kas osaliselt või täielikult ka nõukogude estraad. Oleks vale väita, et varem pole Eestis püstijalakomöödiat kunagi esinenud - koomilise repertuaariga üksikesinejaid leidus varem külapidudel ja kõrtsides, nad astusid üles kabareeprogrammides ja hiljem estraadilaval - kuid tõsi on see, et puhas stand-up tuli Eestisse koos Comedy Estonia tekkimisega. Millised on siis estraaditähtede seosed anglo-ameerika standupiga? Esiteks, ka estraadinäitleja oli laval ilma abivahenditeta (vastupidiselt komöödianäitejale, kelle kasutuses on kunstniku poolt loodud lavakujundus) ning pidi publikule muljet avaldama oma isiksuse või kehastatava karakteriga. Kui esineja (olgu siis selleks näitleja või teadustaja, kes pidi publikut lõbustama etteastete vahel) astus estraadilavale, oli tema eesmärgiks võita publik enda poole esimeste minutitega. Kui seda ei juhtunud, võis ennustada ka edasise edu puudumist. Nii estraadinäitlejat kui ka stand-up artisti eristab tavalisest näitlejast asjaolu, et mõlemal puudub "neljas sein" publikuga. Siin tuleb sisse teine tingimus - otsene suhtlus esineja ja publiku vahel. "Neljanda seina" puudumine tähendas seda, et esineja räägib oma lugusid koostöös publikuga; see toimus teatud piirini ka estraadi puhul. Esineja sai publikult vihjeid, mida etteastele lisada ja mida välja jätta (oma kogemusest on kirjutanud näiteks Möldre 2010), ja hea näitleja oskas neid vihjeid enda kasuks tööle panna. Samas esitasid estraadinäitejad siiski eelnevalt kontrollitud ja paika pandud repertuaari, mis oli läbinud tsensuuri karmi kadalipu. Seetõttu oli improviseerimist oluliselt vähem kui püstijalakomöödias keskmiselt. Kolmandaks, ka estraadietendus toimis hetkes, kuigi seda vähemal määral kui stand-up, sest spontaansust nii esineja kui publiku poolt pärssisid juba mainitud ranged kontrollimehhanismid. Arvata võib, et sellegipoolest reageerisid esinejad publikule, sest estraadietendus koosnes tavaliselt mitmetest sketšidest ja õhtujuhi kommentaaridest, millest viimane oli vabamas vormis ja vajadusel ka publikut ning hetkesündmusi arvestav.

Põhiliselt eristab estraadi püstijalakomöödiast asjaolu, et estraad säilitas lõpuni sarnasuse kabaree- või varieteežanriga, kus õhtu jooksul vahelduvad erinevad meelelahutuslikud etteasted. Lavale võisid ühe õhtu jooksul tulla nii komöödiasketšid, tantsunumbrid kui ka laulud. Stand-upi stampkuvand üksi mikrofoniga pubilaval seisvast inimesest ei olnud selleks ajaks veel materialiseerunud. Double rõhutab (2005), et laval peab seisma vaid üks inime- 
ne - esineja, keda juhatab küll sisse õhtujuht ehk compère / MC (Master of Ceremonies), kuid kes naljade esitamise ajal on üksi. Estraadilaval tuli sageli ette, et humoresk oli mõeldud rohkem kui ühele inimesele (eriti raadios edastatavas "Meelejahutaja" saates esines korraga samas etteastes rohkem kui üks näitleja, igaühel erinev roll, selle asemel et üks näitleja kehastaks järjest kõiki rolle ise). Kolmandaks ja eelnevaga seotud oluliseks erinevuseks oli tõik, et esinejad ei pidanud alati oma teksti peast teadma, vaid võisid seda ka maha lugeda (sedagi eelkõige raadioesinemistel).

\section{Materjal}

Analüüsis vaatleme mõlema perioodi materjali, et kirjeldada detailsemalt estraadi ja stand-upi erinevusi, eriti neid, mis puudutavad teemavaliku seoseid populaarsuse ja staatusega ühiskonnas. Selleks võeti valimisse kolm teksti nõukogude estraadi repertuaarist, keskendudes nendele tekstidele, mis olid siis ja on jätkuvalt publiku lemmikud. Sümboolne staatus ja väärtus, mille need tekstid juba siis omandasid, on kandunud kultuurimällu (Assmann 2006: 8) ning muutunud oluliseks kultuuritekstiks mitte ainult toonastele vaid ka järgnevatele põlvkondadele. On alust arvata, et populaarseim estraadirepertuaar annab parima ülevaate teemadest ja koomilistest vahenditest, mida estraadilaval edukalt kasutati. Populaarseimate tekstide valikukriteeriumiks kasutati erinevate estraadiklippide vaatamissagedust YouTube'i keskkonnas. Selleks eraldati kõik otsingutulemused märksõnale "estraad" ja "humoresk" ning järjestati nende klikkimissageduste alusel. Ainult ühe internetiallika (YouTube’i) kasutamist õigustas fakt, et YouTube on Google’i kõrval olulisuselt järgmine otsimootor internetis (üle $60 \%$ otsingutest tehakse nendes kahes keskkonnas) ning sisaldab kõige rohkem/valiidsemaid andmeid kasutajate eelistuste kohta. Kolm enimvaadatud estraadiklippi transkribeeriti ja nende sisu kategoriseeriti teemade alusel. Need olid "Tehnikaajastu" (35 064 klikki), "Kahtlused" (21 990) ja "Kunstisaalis" (20 002). Kõigi kolme teksti originaal on venekeelne: tuntud humoreskikirjaniku ja artisti Mihhail Žvanetski tekste tõlgiti eesti keelde palju ja fakt, et kolm populaarseimat teksti pärinevad tema sulest, osutab ilmekalt tema tekstide edukusele. Esimene ja kolmas tekst valmisid 1960. aastatel ning teine ("Kahtlused") järgmisel kümnendil.

Uurimismaterjali teise osa moodustavad stand-up esinemised aastatest 2010-2012 Tartus. Avalikel esinemistel pubides (Möku ja Vilde) salvestati 21,4 tundi audio- ja videomaterjali, millest osa on transkribeeritud ning mis loodetavasti salvestiste/transkriptsioonide lisandudes moodustavad taasiseseisvunud Eesti Vabariigi varase stand-upi andmebaasi. Et analüüsi eesmärgiks seati tähtsaimate ja korduvate teemade kirjeldamine ja esineja/auditooriumi 
roll teemavalikus, siis valiti teisest perioodist välja tekstid, mis iseloomustavad Comedy Estonia rühmitust tervikuna ja on samal ajal iseloomulikud ka konkreetsetele esinejatele. Kui stand-up esineja kandis sama teksti ette erinevatel õhtutel, võeti valimisse esimene esitamiskord.

Läbivate teemade kategoriseerimiseks kasutati kvalitatiivse analüüsi programmi QDA Miner, milles märgistati kõik sketšides esinevad teemad ning selgitati välja neist enimesinevad.

\section{Analüüs ja arutelu}

\section{Nõukogude aeg: estraad}

Estraaditraditsiooni sotsiaalse tausta moodustas poliitiline olukord: igapäevaelu absurd, poliitilised repressioonid ja tsensuur, vastuolu ideoloogia ja tegelikkuse vahel jms. Estraad kasutas kõike seda inspiratsioonina viisil, mis pidi olema tabav ja kriitiline, kuid samal ajal ametlikult vastuvõetav. Pärast Estraadistuudio sündi 1963. aastal hakati selles Eesti Filharmoonia alla kuuluvas asutuses otsima ja koolitama uusi talente. Estraad sai koheselt väga populaarseks. Näitlejatel tööst puudust ei olnud: nagu sel ajal aktiivselt lavalaudadel esinenud estraadiartistid meenutavad, toimus 40 aasta jooksul ca 4500 etendust (intervjuu Aino Himbekiga, Randalu 2001), ning lisaks sellele loendamatul hulgal haltuuratöid privaatsetel üritustel (pulmades, kolhoosipidudel jm). Elava publiku juuresviibimisel salvestatud estraadiprogrammid, mida edastati kas raadios või televisioonis, tekkisid varsti pärast seda. Pileteid neile salvestustele oli nii raske saada, et neist sai omamoodi valuuta (intervjuu Eino Baskiniga, Laks 2009). Näitlejad, keda publik kõige rohkem hindas ja lavale ootas, püsisid läbi nelja aastakümne samad: Eino Baskin, Ita Ever, Sulev Nõmmik ja nii mõnedki teised kehastasid nõukogude inimese jaoks estraadi. Repertuaar koosnes eelkõige tõlgitud materjalist, kuid ka eesti humoreskikirjutajate (nt Priit Aimla) originaaltekstidest.

\section{Teemad}

Estraadinäitlejate suur populaarsus ja nende lausa müütiline staatus pani peale kohustuse kõnetada kuulajate jaoks olulisi teemasid, ilma et tsensuur etteasteid ära keelaks. Mõned populaarseimad neist püsivad siiani kultuurimälus, isegi kui teemad pole enam aktuaalsed. Sagedaimini esinev teema oli nõukogude igapäevaelu. Sinna alla kuulub puudujääkide kirjeldamine (nt kaupade puudus poodides): 
Mul on kõik kaup kodus olemas! Absoluutselt kõik. Vann on ääreni täis: mul on kruupi, tangu, riisi, mannat, mul on suhkur, mul on vann täis! Vett, vett, vett, vett! [naer] Mida te mõtlesite? Vett! Äkki keeravad kraani kinni! [naer, plaksutamine] Parem ikka kui on, kui lubatakse, et on. Mina küsisin, nemad lubasid. [naer] (http://www.youtube.com/watch?v=rHrz $\mathrm{kKkYMDk \& feature}=$ related)

Peaaegu sama oluline pilkeobjekt oli rumal nõukogude elanik/ametnik. Rumaluse pilkamine tööpostil oli lubatud, isegi soovitatud, sest see oli kooskõlas ideoloogiaga, mis keskendus just väiksematele pahedele nagu tööluus, alkoholi liigtarbimine või haltuura, selle asemel et tõelisi ja suuremaid valupunkte märgata. Rumal nõukogude inimene, kes tekitab oma ebapädevusega hulgaliselt rahvusvahelisi probleeme, on humoreski "Tehnikaajastu" teemaks. Selles saadetakse tehnikakauge ametnik koos asjassepühendamatu lüpsineiuga Pariisi tehnoloogianäitusele tutvustama leiutist, mille tegelikult autorile ei antud välisviisat:

Rahvast murdu! Ja kõik räägivad puhtas prantsuse keeles. In-in-intelligentsed inimesed. Valdavad võorrkeeli. [naer] Mina esinesin kõnega. Ütlesin puhtas prantsuse keeles - läbi tõlgi muidugi-ütlesin: "Messieurs et madames" - ütlesin: "C'est la vie.” Kolm korda ütlesin. C'est la vie, c'est la vie, c'est la vie. Siis ütlesin veel. "Boeuf a la tartar [naer], salad olive, boeuf strogonov. [naer]"

(http://www.youtube.com/watch?v=BaalZCfgVO0\&feature=related)

Muidugi pidid esinejate poliitilised avaldused jääma hoolikalt varjatuks, samas kui koomikud suutsid tsensuuri kiuste peita esitatavasse teksti keelatud sõnumeid ja hoida seega publikut pidevalt valvel. Avastamise korral ootasid esinejat sanktsioonid kuni pikaajalise lavakeelu ja vangistuseni välja. Selle tulemusena olid estraadinäitlejad väga osavad peidetud sõnumite edasiandmisel, tehes seda vahel mitte sõnade vaid kõnekate pauside ja rõhuasetuste kaudu. Eino Baskini esitatud sketšis "Kahtlused" töötab koomilisena just mehhanism, milles näiliselt neutraalne sõna "süsteem" (kontekstist tuleb välja, et mõeldakse maja veesüsteemi) hakkab toimima kahemõtteliselt, kuigi esiplaanile seatud tähendus jääb rangelt võttes mittepoliitiliseks.

Meie-meie majavalitsuse korraldusel pandi meie ukse peale täna pisike silt. Si-silt pandi. Mitte sült. Silt, silt, silt! [naer] Silt pandi välja. Ja sinna sildile oli kirjutatud et ... eee.. kolmeks päevaks võetakse kuum vesi ära. Naljakas küll: enne ei olnud kaks kuud, nü̈̈ võetakse kolmeks päevaks välja. [naer, aplaus] Ma küsisin majavalitsuse töötajatelt, et milles on asi - nemad ütlevad, et viga on süsteemis. [paus, naer] Mingi toru on umbes 
juba ammu. Roostes on. Nü̈̈d puhuvad kompressoriga läbi, nii et paari päevaga saab asi korda. [naer] (http://www.youtube.com/watch?v=rHrz $\mathrm{kKkYMDk} \&$ feature $=$ related)

Esineja avaldusele, et "viga on süsteemis", järgneb üsna pikk paus (3 sekundit) ja naergi on pigem tagasihoidlik, sest tegemist on potentsiaalselt ohtliku väljaütlemisega. Kui aga järgneb selgitus sellest, kuidas toru oli umbes ja asi saab õige pea korda, tormiline naer, mis justkui peegeldaks publiku kergendust ja pakub uue märguande, mille järel on turvaline naerda - olgu siis nalja objektiks totalitaarne või veesüsteem. Sama humoreski sees on veel teisigi kohti, kus naer järgneb just sellele, mis on ütlemata jäetud. Poliitiliselt ohtlik tõlgendus justkui ripuks esineja ja publiku vahel, kes teavad, et see on olemas, kuid sõna-sõnaliselt järge ajades on kõik poliitiliselt korrektne:

Mul on petrooliumilamp kahe tagavaraklaasiga. Taht, taht on olemas. Priimus - phh-phh-phh - [naer] mäletate, jah? Teie mäletate, aga minul on. [naer, aplaus] Tünn petrooli, kast seepi, ämber penitsiliini, nelisada meetrit sidet, kuus kilo vatti, kaks liitrit joodi... Aga äkki ühel ilusal päeval tulevad ... [pikk paus, naer, aplaus] Halvad... halvad ilmad tulevad! [naer] Mis te rõõmustate?

(http://www.youtube.com/watch?v=rHrzkKkYMDk\&feature=related)

Umbmäärased "nemad/need", kelle tulekuks mina-tegelane end ette valmistab, kombineerituna pika pausiga, paneb publiku maruliselt aplodeerides naerma, pärast hetkelist kahevahelolekut, mis viitab jällegi sellele, et osad kuulajad alles ootavad luba naermiseks. Tugev positiivne reaktsioon jätkub pärast seda, kui pinge on maandatud sõnadega "halvad ilmad tulevad!", mis ühest küljest vähendab varasemate sõnade poliitilist tähendust, kuid teisalt rõhutab seda, mida ei saa otse välja öelda.

Estraadiesineja võtab laval omaks mitmeid erinevaid lavategelasi, mille hulgas tõuseb esile "negatiivne isend". Selleks võib olla mistahes marginaalne tegelane, kellel on ühiskonnas stigmatiseeritud staatus. Kõnealustes näidetes on negatiivseks isendiks seal rääkivad mina-tegelased, kes kõik on mingil moel väljaspool seisjad: paranoiline naaber ("Kahtlused"), ebaintelligentne ülemus ("Tehnikaajastu"), või joobes inimene ("Kunstisaalis"). Nendest viimane räägib oma kogemusest kunstinäitusel, kuhu ta läks "kultuurselt puhkama". Sketš sisaldab hulgaliselt märksõnu, mis tänapäevaks on muutunud käibefraasideks; vaatamata sellele puudub humoreskil "Kunstisaalis" poliitiline alatoon ning ka selle esitamise ajal ei pilanud see mitte totalitaarset süsteemi vaid igapäevaseid pahesid nagu joomine:

Ma ütlesin talle vaikselt, ma ütlesin talle intelligentselt: "Mis asja sa sisised, valge hiir! Mis asja sa sisised! [naer] Sa näed, mul on poolik 
käes, mul pole klaasi. [naer] No võtsin sealt ühe väikse vaasi - mis taga ikka juhtub, see vaas on ju rauast! [naer] - "Kuidas teil häbi ei ole, see vaas on üheksateistkümnenda sajandi biidermeier." - "Ise sa oled üks biidermeier!" [naer]

(http://www.youtube.com/watch?v=H2irYp-dv7M)

\section{Post-sotsialistlik komöödia: Comedy Estonia}

Comedy Estonia alustas juunis 2010 väikese publiku ees Möku pubis Tartus, kuhu oli kogunenud umbes 30 inimest. Esimesel komöödiaõhtul pandi paika reeglid, mida stand-up žanrit kuulama tulnud publik peab teadma:

Natukene publikuga suhtlemisest, me peaksime vist alustama sellest. Minu arvates on praegu just õige aeg üheks grupiviisiliseks "Bööö!!"karjumiseks. Kas me võiksime nü̈̈ seda kõik koos proovida, sest siiani on meie sõu olnud üsna vilets. [“Bööö!”] Jah, ja nü̈̈d kõik koos: "Bööö!” ["Bööö!"] Super! Aitäh! [naer] Ja sellega käib kaasas selline žest [näitab pöidlaga allapoole]. Suurepärane. Fanstastiline. (MC, Eric, 08.06.2010)

Esimene komöödiaõhtu võeti väga soojalt vastu ja info uue meelelahutusvõimaluse kohta levis kiiresti. Järgnes hulk õhtuid suuremates pubides, kus viibis juba rohkem kuulajaid. Ka igakuine komöödiaüritus Mökus jätkus, ja uued esinejad katsetasid oma võimeid vaba mikrofoni ees. Aasta jooksul arenes algselt kitsa ringi üritusest välja terve liikumine, mille tuumikul on nüüdseks ka oma äriline ettevõte. See korraldab välisartistide Eestisse tulekut (nt Dylan Morani esinemine Vene Teatris kevadel 2012), igakuiseid etteasteid Tallinnas ja Tartus, ringreise, ning selle kaudu saab tellida Comedy Estonia stand-up artiste esinema näiteks firmapidudele ja mujale. Uue publiku otsimisel on põhirõhk nüüd Tallinna üritustel (põhiliseks toimumiskohaks on seal Club Privé), kuid ka Tartul on oma roll, eriti Möku pubil, kus Comedy Estonia oma tegevust alustas. Tuumikusse kuuluv Louis Zezeran on intervjuus öelnud, et nad eelistavad jääda kindlate esinemiskohtade juurde, sest see on stand-upis tavaline praktika: "Praegusel hetkel on meil loetud arv kohti [kus me esineme], ja me teeme nendega tihedat koostööd, et inimestel tekiks neist kuvand kui kohtadest, kuhu tullakse komöödiat vaatama - me ei esine igas kohas, mis linnas leidub" (Zezeran 22.02.2012). Suvel 2012 proovis Comedy Estonia ka komöödiatuuri formaati, külastades eestikeelse komöödiaõhtuga nelja väiksemat Eesti linna (Viljandit, Pärnut, Kuressaaret ja Rakveret). Sellel ideel on ühisjooni estraadiga, mis samuti tegi ringreise linnast maale kultuurimajadesse. 


\section{Teemad}

Eesti laval esineva välismaalase esimene loomulik teemavalik on kohanemine Eesti eluga. See paneb (eestlasest) kuulaja vaatama ennast teise pilguga, avastama kohalikke veidrusi ja julgustab enda üle naerma. Publiku välismaalastest osa näeb aga esinejas kedagi, kes on tähele pannud sarnaseid asju nagu nad isegi. Need on teemad, millega kogu auditoorium saab samastuda, kuid mida nad ise ei oskaks selliselt sõnastada. Kultuurierinevused on seega esimene ja viljakas valik, millest publikule rääkida. "Negatiivse isendi" marginaalne kuvand - käsitletaval juhul inimene, kes pole täielikult kohanenud kohalike olude ja inimestega - aitab ka siin mõista just selle teema populaarsust. Vaid kõrvalseisja oskab esile tuua aspekte kohalikust kultuurist, mida põliselanik ei oska märgata, kuid mis pakuvad rõõmsat äratundmist. Esineja on "teine", võõras, kes kannab ette oma vaatepunkti "meist", kuulajatest:

Sissehingatud kõne. [pikk paus] See on üks huvitavamatest ja isikupärasematest nähtustest, mida ma Eestis elamise juures armastan. Noh, inimesed on väljahingamisest küllalt rääkinud. Aga kuulake nü̈̈d mind: iga väljahingamise kohta on üks vastassuunaline, samaväärne sissehingamine. [naer] See on tõsi. Ja kui sul veab, siis vahel kuuled sa inimesi seda tegemas lause keskel. See on justkui sellest, et asi, millest nad räägivad, on nii tähtis, et nad unustavad hingamise ära. "Jaa, tead, ma ostsin selle kleidi paar päeva tagasi ja see oli [sissehingamisel] > täiesti jumalik!<” [naer] Aga vahel harva juhtub nii, et sa kuuled ühes lauses täielikku hingamistsüklit [naer], kus inimesed räägivad alguses normaalselt, siis räägivad sissehingates, ja lõpetavad lause jälle normaalselt rääkides "Kuule, kallis, proovi >seda kleiti siin<, ma tahaks teada, kuidas see sulle sobib." [naer] Aga veel harvematel juhtudel on terve lause sissehingatud. [naer] Selle jooksul hingab inimene nii palju õhku sisse, et kopsudes lihtsalt pole rohkem ruumi. Nad ei suuda sinna rohkem õhku sisse pigistada. Aga nad räägivad edasi. [naer] ">jah, tõesti, ma sain omale khakhhahhh. [naer] Khkhkhahh<.” (Stewart, 08.06.2010)

Teine näide räägib samuti välismaalase kogemusest Eestis, kus Eric Seufert (üks Comedy Estonia asutajatest) võtab vaatluse alla eestlaste passiiv-agressiivse ohke. Otsustades publiku reaktsiooni järgi, on tegu omadusega, mis pakub kuulajatele rõõmsat äratundmist:

Teenindus võib olla Eestis tõeliselt halb. Teate, üks asi, millega siiski võib ära harjuda, on... Ma arvan, et eestlased kui rahvus on omal moel viinud täiuslikkuseni passiiv-agressiivse ohkamise kunsti. [naer] Ohhhhhhh. [naer] Kui ma siia kolisin, siis tahtsin avada siin pangakontot ja ma olin õppinud umbes terve suve eesti keelt, nii et ma tahtsin seda 
teha läbinisti eesti keeles. See võttis terve igaviku ja minu taha tekkis järjekord. Ja see kõlas sõna otseses mõttes nii, justkui ma viibiks astmahaigete ooteruumis. Viisteist inimest kõik ohkavad: "Oehhhhhhh." [naer] Ma arvan, et eestlastel on šerpade kopsumaht. Ma ei tea, miks eestlased ei võiks korraldada ekspeditsioone Mount Everestile. Vahiksid terve tee oma kingi, ei võtaks kellegagi silmsidet, jõuaksid tippu, teeksid seal mingi sarkastilise märkuse: [tormiline naer, plaksutamine] "No see oli küll kiire... oehhhh.” (Eric, 04.06.2010)

Mõlemad sketšid pilavad eestlaste suhtlusstiili. See ei tule muidugi üllatusena, et paljud naljad puudutasid juba esimestel komöödia-õhtutel just seda teemat. Silmast silma suhtlus on esimeste muljete vormija ja esimesed tugevamad mälestused uuest keskkonnast pärinevad just sellest kanalist. Anekdooditraditsioonis (sh vanades naljandites) on tekste, mis puudutavad lingvistilisi erinevusi või veidrusi. See teema on olnud ka rumaluse-skriptiga naljade baasiks (vt Davies 1990) juba varastel aegadel ja pea igas kultuuris. Kui aga esimesed muljed otsesest suhtlusest uue kultuuri esindajatega on lahtunud, jõutakse sügavamale tasandile, mis ei räägi ainult suhtlus- või rääkimisviisist, vaid kuhu kuuluvad tähelepanekud inimeste harjumustest ja eripäradest.

Kui on olemas üks asi, mis ma [Eestis] olen õppinud, siis on see see, et kui eestlased lähevad ostude eest kassasse maksma, siis nad armastavad väga kasutada eralduspulka erinevate klientide vahel. Ja ma olen seda juba aastaid pü̈̈dnud mõista, kuni ühel päeval [naer] läksin ma toidupoodi ja hakkasin just minema kassase, et oma ostu eest maksta, ja minu ees oli üks teine kutt kes seal ootas, et kassiir lööks sisse tema viimase ostu, mis oli... no ma ei tea... karp mune. Ja mina tahtsin lihtsalt midagi kerget näksida, mul oli umbes nagu.. üks banaan, ja ma panin selle kassalindi tagumisse otsa. Meie kaupade vahel oli vähemalt meetrijagu maad. [naer] Aga ma ei pannud sinna vahele eralduspulka, ja sellele tü̈̈bile ei meeldinud see üldse. [naer] Ta vaatas siia... ja vaatas banaani... vaatas mind... vahtis mind tükk aega... ja ta ei suutnud seda taluda! Ta haaras eralduspulga ja lõi selle pauguga vastu kassalinti. [naer] Ja pärast kõiki neid aastaid, ku ma üritasin sellest [eralduspulga probleemist] aru saada, järsku koitis mulle: Eestis lihtsalt peab olema eralduspulk ühe mehe munade ja teise mehe banaani vahel! [tugev naer ] (Stewart, 07.09.2010)

Vahel tehakse ka nalja Eesti elustiili või riigi üle tervikuna, jättes eestlaste veidrused mängust välja. Järgmises näites võetakse vaatluse alla jaanipäev, mis ei möödu ilma suurema alkoholijoomise ja maal käimiseta.

Päev pärast jaanipäeva oli mul veidi suitsiidne meeleolu. [naer] Ma läksin autoga sõitma. Tegelikult olen ma päris üllatunud, et meil on siin täna 
nii palju rahvast, sest tegelikult sel nädalal on Eesti suletud. Misiganes, Läti sõjavägi võib Eestisse tungida. Keegi ei paneks tähelegi kuni esmaspäevani, kui inimesed tulevad maalt tagasi. [naer] Viis päeva järjest on ainuke asi, mis seisab Eesti ja tema vaenlaste vahel, pagana sääseparved! [naer] (Andrei, 04.06.2011)

Aja jooksul muutuvad sõnastamata piirid välismaalastest esinejate - out-rühma - ja eestlastest publiku vahel hajusamaks. Teemadesse sugenevad mõtisklused sellest, kuidas näeb eesti elu siin hästi assimileerunud sisserändaja. Mõnikord tulevad jutuks detailid, mida võhikust välismaalane ei saakski teada. Järgnev nali Stewartilt kombineerib kultuuritundmisest märku andvaid detaile Eesti elust, millest arusaamiseks peab nendega hästi kursis olema:

Mul on väga piinlik aga... ma arvasin aastaid, et Eesti kõige populaarsem kirjandusteos on 15-köiteline armastusluule kollektsioon, mis oli pühendatud naisele nimega Ene. [naer, plaksutused] (Stewart 10.04.2012)

Selles naljas viitab ta endale kui Eestis elavale isikule, kes väga piinlikul moel on seni olnud teadmatuses sellest, et Ene ei tähista Eestis mitte ainult tuntud naisenime, vaid ka on lühend Eesti Nõukogude Entsüklopeediast. Samas vihjab ta, et teab nüüdseks mõlemat tähendust ja on seega ka oma publikuga lähedasem; st ta omab infot, mis siseringi teadmisena on muidu kättesaadav ainult eestlastele. Kuid ka tema algne arvamus, et $E N E$ on armastusluule kogumik, näitab juba palju täpsemaid teadmisi Eesti elust kui seda võiks oodata põliselt Lõuna-Carolina ameeriklaselt.

Publikuga samastumine või lähendumine on nähtav ka naljades, kus artist räägib oma rahvuse eripärast kohaliku publiku silme läbi, kasutades selleks stereotüüpe, mis tema rahvuse kohta siin (või ka mujal maailmas) käibivad. See justkui näitab, et ta eemaldub mõtteliselt oma "teise" positsioonilt, kuid samas ei muutu ta sellest sõltuvalt otse üheks publiku hulgast vaid jääb ikkagi truuks marginaalsele vaatepunktile, milles ta pole ei täielik ameeriklane/ austraallane vm, ega ka täieõiguslik kohalik eestlane.

Millal iganes ma ameeriklastega rääkima satun, nad küsivad minu käest alati et noh, kus sa siis elad, ja mina vastan siis, et Eestis, ja sellele järgneb alati selline kohmetu vaikus. Nad pole justkui päris kindlad, millest ma räägin. Noh, ega ma ei taha neid välja aidata ka, ma lihtsalt lasen sellel pausil sündida. -“Kus sa elad?” - "Eestis.” [väga pikk paus, naer] - “Ja kus see asub?” - “Oh, see asub Läti vahetus naabruses.” [naer] (Stewart, 16.08.2011)

Stewarti repertuaaris on eriti hästi nähtav sujuv vaatepunkti muutumine: võõrast saab aina rohkem oma, ja tänu sellele kasvab vastastikune mõistmine 
publikuga. Ta pole enam päris võõramaalane. Tema puänti lisandub detaile, mis lähendab teda kuulajatega, kuid ta ei samasta end nendega täielikult. Pigem on kadunud esimese kontakti pealiskaudsus, asendudes sügavamate teadmistega kohalikust elust. Stewart loob uue identiteedi, mille kohaselt pole ta päris ehtne eestlane, kuid ta on asendamatu osa sellest siseringist, kes tulevad kuulama püstijalakomöödiat. Selles ringkonnas aktsepteeritakse teda kui oma ja isegi autoriteeti. Stand-up huviliste ringkonna moodustab kirju kooslus inimestest, kes tunnevad seda žanrit, oma esinejaid ja iseennast ning kes on valmis nii enda kui ka teiste üle naerma. Seesama fännide kogukond tunnetab teda autoriteedina, kellel on õigus välja öelda, mida tema (ja ka nemad) elust ja asjadest arvab. Nad on andnud talle eelpoolmainitud "koomiku loa", õiguse naljarääkimiseks, ja nad on valmis naerma juba enne puändi ärakuulamist, sest nad eeldavad, et kuigi mitte päris oma, oskab ta sõnastada ka kuulajate tundeid. Stewart on nende jaoks muutunud tuntud lavaisiksuseks, ja isegi kui nad teda tegelikkuses ei tunne, võib auditooriumil tekkida arusaam, et nad teavad teda, tema naist ja lapsi, tema eluvaateid. Selles mõttes, just esinemissituatsioonis, on ta muutunud nende silmis omaks, ja tema tugevus on oskus liigelda sujuvalt "oma" ja "võõra" kategooriate vahel. Ka Woody Allen on öelnud, et publik "tahab, et esineja oleks meeldiv ja naljakas. Suurim viga, mis esineja saab teha, on [ignoreerida isiksuse mõju ja] üritada ainult sõltuda oma materjalist" (tsiteerinud Nachman 2003: 546).

Analüüsitud kaheaastase perioodi lõpupoole muutuvad sagedasemaks viited päevapoliitikale ja uudistele. Käsitlust leiavad kiiruskaamerate paigutamine Tallinna-Tartu maanteele, Poola lennuki hädamaandumine Ülemiste järves, samuti kuulujutud eesti poliitikute kohta:

Mis on ühist kiirabiautol ja Katrin Siskal? Mõlemaga on sõidutatud üht paksu vanameest. [naer] Ma rääkisin sedasama nalja Vabaduse väljakul Tallinnas, Tallinna linnavalitsuse kõrval, ja mulle pakuti biljon krooni tähistamata kupüürides selle eest, et ma räägiksin nalju hoopis Ansipist. Nii et "Kop-kop!” [publik: "Kes seal on?"] - “Ansip” [publik: "Mis Ansip?"] - "Seda küsivad kõik järgmiste valimiste ajal ka!" (Andrei, 16.08.2011)

Sellele vaatamata pole poliitikast saanud peamine kõneteema, kuigi traditsiooniliselt on näiteks anglo-ameerika stand-up vägagi poliitiline. Põhjuseid on mitmeid: eesti publik ei oota välismaalastest esinejatelt kohaliku poliitika tundmist; pealegi ei peeta väljaspool seisja kogemust küllaldaseks, et ta võiks lahata Eesti riigi sisepoliitikat. Välismaised esinejad ei ole selles osas veel publiku usaldust pälvinud. Samal ajal ei leia ka välismaalastest koosnev osa publikust selle teemaga piisavalt kokkupuutepunkte. Nii jääb parima strateegia ja teemavalikuna esiplaanile siiski välismaalase elu Eestis, nende marginaalne positsioon - eemal oma tegelikust päritolumaast ja võõrad ka kohalikele. 


\section{Estraad ja stand-up: staatus ühiskonnas ja publiku ootused}

Järgnevalt tuleks küsida, kuidas on mõlema žanri populaarsust mõjutanud muutused esineja positsioonis, teemades või koguni žanris endas. Estraad sündis ühelt poolt soovist kommenteerida lubatud moel nõukogude igapäevaelu, teisalt aga vajadusest pakkuda rahvale legitiimset meelelahutust, et juhtida neid kõrvale režiimi seisukohalt ohtlikumatelt tegevustelt. RAMETO (Raadio Meelelahutussaadete Toimetus) esimese toimetaja Priit Aimla sõnul oli tegemist poliitiliselt motiveeritud soovitusega, et kaudselt keelustada kirikus käimine (intervjuu Priit Aimlaga, Kulli 2005). Etendused muutusid kiiresti väga populaarseks ja pidev vajadus uue materjali järele mõjutas autoreid pöörduma toonaste vennasvabariikide huumoritoodangu poole. Palju humoreske, sh populaarseimad, olid tõlgitud vene keelest ja juba varem oma headust lavalaudadel tõestanud. See fakt isegi tõstis nende asjakohasust ja väärtust rahva silmis. Samal ajal peeti komöödiat läänelikuks žanriks, ja see lisas staatust veelgi: estraad, mis läbis enne lavale tulekut tiheda tsensuurikadalipu, muutus seega ihaldusväärseks, keelatuks. Ometi oli estraad ka piisavalt "oma”, käsitledes kohalikke teemasid ja kujutades maailma väljaspool Nõukogude Liitu ettekirjutuste kohaselt üksnes negatiivselt. Kuigi estraad oli lubatud žanr, kontrolliti selle sisu, enne kui trupp võis etendusega lavale minna. Estraadikunstnikud olid väga populaarsed avaliku elu tegelased ja nende esitatud humoreskid või laulud muutusid kiiresti osaks folkloorist. Nende suurt mõju arvamusliidrina tunnetasid ka tsensorid, kes hoidsid neil pidevalt silma peal; avalik meedia ja nõukogude võimuladvik suhtus neisse tähelepaneliku reserveeritusega (intervjuu Rein Klinkiga, Arusoo 2001). 1950. aastal toimunud Eestimaa Kommunistliku (bolševike) Partei Keskkomitee VIII pleenumil soovitati muuta estraad elulähedasemaks: estraadilaval pidi esitatama lihtsaid õpetlikke lugusid, mis on suunatud tavalisele töölisklassi esindajale, selmet kasutada satiiri, mitmetähenduslikkust ja keerulisi kujundeid. Üks esimestest estraadietendustest "Kuu peale" rääkis kilplastest, kuid juba sellegi teksti oli põimitud vihjeid ja mitmetimõistetavusi, mis olid kriitilised kohaliku režiimi suhtes. Näitlejad on meenutanud, et üks stseenidest sisaldas lauset "Kes väikse või suure linnuga / kuid tähtsaid asju ajavad võrdse innuga." See rumalate juhtide pihta käiv kriitika jäi tükki sisse ja sellisena mängiti seda sadakond korda, enne kui etendus lõpuks ootamatult kavast maha võeti (intervjuu Lia Laatsiga, Kerge 2000). Ei olnud ka haruldane, et näitlejaid küsitleti, nende tegutsemisvabadust piirati või nad lausa vahistati (Möldre 2010). Vahel oli tegu vaid linnalegendidega: kuulujutud levisid kulutulena ka juhul, kui näitleja oli vaid ära sõitnud või haigestunud, mitte arreteeritud. Nende ohustatud positsioon andis näitlejatele 
rahva seas veelgi positiivsema staatuse, vaatamata sellele, kas juttudel oli tõepõhi all või mitte.

Peamine teema humoreskides oli rumalus ja sotsiaalsed pahed nagu ahnus või ülbus (vt ka Lõhmus 2012), ja seda tervitas soojalt ka publik. Lõhmus lisab: "[raadio- ja televisioonihuumori] staatus oli sel ajal väga kõrge [...] Estraadietendusi lindistati erinevates paikades üle kogu Eesti (kolhoosides, klubides, töökollektiivides, jne) ja see tõi naljad auditooriumile lähemale, samal ajal olles ise naljade ammendamatuks allikaks" (Lõhmus 2012: 148). 1970. ja 1980. aastatest pärit igihaljaste tekstide hulk tõestab, et need sketšid on inimestele olulised ka tänapäeval, isegi kui alltekst pole enam sama või pole ajuti arusaadavgi: nende tekstide väärtus on nostalgiline ning nende funktsiooniks on olla kultuurimälu kandja, rahvuse eneseidentifitseerimise teetähis. On oluline rõhutada, kuidas estraad ühendas tervet rahvust. Jällegi Lõhmust tsiteerides oli estraad "kollektiivne harjumus, mis oli situatiivne ja samas diakrooniline" (Lõhmus 2012: 148). Range tsensuur ainult suurendas žanri populaarsust; see motiveeris inimesi käima kogu kollektiiviga estraadietendustel, kuulama ja vaatama huumorisaateid, otsides seejuures poliitiliselt korrektse pealispinna alt pidevalt peidetud sõnumeid.

Comedy Estonia strateegia publiku enda poole võitmisel on olnud veidi erinev. Esiteks on erinev terve sotsiaalne ja poliitiline taustsüsteem, mis ei nõua enam keelatud emotsioonide vabastamist lubatud moel ja keskkonnas ametlikke reegleid keelatud sisu kohta pole. Samas oli vajadus komöödia järele iseseisvumisjärgsel perioodil tugev, sest pärast taasiseseisvumist paisati lavadele ja eetrisse erinevaid žanre, millest ükski ei saavutanud märkimisväärset populaarsust või domineerivat positsiooni. Publik ootas kvaliteetset komöödiat. Comedy Estonia alguskuud olid korraldajate sõnul üliedukad: "Kui [stand-up õhtule] tuli kohale 170 inimest, teadsime kohe, et oleme õigesse kohta sattunud. Meie sõud on praegugi iga kuu välja müüdud" (intervjuu Louis Zezeraniga, Turner Garrison 2012). Potentsiaalset publikut informeeritakse eelseisvatest üritustest mitteformaalseid kanaleid pidi: eelkõige suhtlusvõrgustikud online- ja offline kanalites, aga ka pubi koduleht või blogi, lendlehed, kuulutused. Facebooki kodulehel on Comedy Estonia kogunud juba üle 3000 järgija ja see on ka ilmselt publikule kõige operatiivsem keskkond uue esinemisinfo hankimiseks. Mulje, et info liigub siseringis ja on eelkõige mitteformaalne, tugevdab rühmaidentiteeti ja kasvatab pühendunud publikut.

Comedy Estonia stand-up baseerub anglo-ameerika eeskujudel. Paljud siinsete püstijalakomöödia õhtute peaesinejad on pärit Skandinaaviast või LääneEuroopast. Sellele vaatamata on Comedy Estonia eestvedajad rõhutanud, et nende eesmärgiks ei ole Lääne-Euroopa ja USA komöödia importimine vaid uue žanri mugandamine kohalikku konteksti. Pärast ühte aastat aktiivset tegutsemist panid Comedy Estonia liikmed sügisel 2011 kokku esimese eesti- 
keelse õhtu. Vilde klubis esinesid Eric Seufert ja Stewart Johnson, aga ka eestlastest amatöörkoomikud Andrei Tuch, Keiu Kriit ja Janika Maidle. Esimene eestikeelne õhtu võeti vastu suure uudishimuga, kuid eestikeelsete esinejate puuduse tõttu pole need regulaarseks muutunud. Selles vallas ootavad publikut ja uurijaid huvitavad muutused - lähiaastate jooksul peaks selguma, kas eestikeelsest stand-upist saab tavapärane nähtus pubilavadel või jääb Eesti stand-up eelkõige ingliskeelseks. Võimalik, et interneti vahendusel žanriga tutvunud publik on sedavõrd harjunud ingliskeelsete sketšidega, et eestikeelne püstijalakomöödia tundub kohatu ega kogu populaarsust. Anonüümne kommentaator, kes vastas artiklile Eesti stand-up ringreisist Pärnu Postimehes, väljendas oma arvamust nii: "Eestikeelene stand-up komöödia? See on samast kategooriast kui "süütu vanaema"." (Roosaar 2012.)

Niisiis, kui tulla tagasi küsimuse juurde, kas kontekst ja sellesse suubuvad välismõjutused soodustavad teatud teemade kasutamist stand-upis, siis tõestust sellele on näha mõlemas perioodis. Teemasid dikteerib nii see, mis on publikule antud hetkel tähtis ja eluline kui ka see, kes on või keda kehastab esineja. Nõukogude ajal tahtis publik kuulda kommentaare igapäevaelu ja absurdse režiimi kohta. Lavaisiksused kujunesid välja sellest lähtuvalt. Postsotsialismis ei mänginud komöödia enam ühiskonnas nii kandvat rolli ja kuulajad olid vastuvõtlikud laiemale teemaderingile, mis ei pidanud vältimatult puudutama vaid "meie"-ringi elu ja kogemusi vaid võisid olla - või olid seda isegi eelistatult - peegeldused väljaspoolt, välismaalaste silme läbi. Siit jõuame küsimuseni, milline on interaktsioon teemade valiku ja žanri populaarsuse vahel erinevatel ajastutel. Mõlema vaadeldud perioodi juures näeme, et publiku suhtumist mõjutas see, milline on žanri staatus. Kuid see ei sõltunud ainult teemadest, mida estraadilaval või stand-up õhtutel käsitleti - lisaks õigetele või vastukaja leidvatele teemadele pidi publik tajuma, et huumor, mida nad kuulavad, on rohkem kui lihtsalt nali; see pidi olema ka eneseidentifitseerimise vahend. Identifitseerimine võis toimuda nii samastumise või (sagedamini) vastandumise kaudu (milles komöödianäitlejal on marginaalse negatiivse isendi roll). Comedy Estonia puhul oli peamine teemavalik välismaalase kogemus Eestis ja eestlaste seas. Kuulajad võtsid selle teema kiiresti omaks ning kahe aasta jooksul täiustasid ja süvendasid ka esinejad oma selleteemalisi nalju, liikudes esmamuljetest sügavamale kultuuritundmise tasandile. Stand-up artistide marginaalne roll väljendub kõiges: nende materjalivalikus, nende lavaisiksuses, samuti esinemiseks valitud inglise keeles. Estraadinäitlejad olid küll eestlased, kuid nende positsioon oli samuti marginaalne. Nad kuulusid erilisse ühiskonnakihti, kellel (nagu narridel kuninga õukonnas) oli kirjutamata luba öelda rohkem kui tavainimesel ja publikul. Vahel pidid nad selle eest ka valusalt maksma poliitiliste repressioonide all kannatades, kuid seda enam hindas neid kuulajaskond. Ka nemad olid negatiivsed isendid, kes jälgisid elu kõrvalt 
ja võisid seda (teatud piirini ja varjatult) kritiseerida. Lawrence Mintzi (1985) käsitlus komöödianäitlejast kui marginaalsest tegelasest, kui hobiantropoloogist peab paika mõlemal juhul ja aitab jõuda neid kahte nähtust, estraadi ja stand-upi, ühendavate seosteni. Roll, mille võtab endale komöödianäitleja, annab õiguse verbaliseerida seda, mida tegelikult välja öelda ei tohi, ei saa või ei oska. See omakorda moodustabki eduka esineja põhitunnuse, sest staatus ja autoriteet tekib koos riskiga, mille võtab end publikust väljapoole seadev komödiant. Teemad, mille kaudu esineja seda teeb, on küll olulised, kuid mitte põhitähtsad, ja need erinevad mõlema perioodi puhul märgatavalt. Eelkõige loeb esineja kohalolek ja isiksus. Niisiis ei sõltu koomiku esinemise edukus ja tema järgnev populaarsus niivõrd käsitletavatest teemadest kuivõrd esineja rollist, lavaisiksusest, milles ta defineerib end võõrana ja mis võimaldab seeläbi ka publikul end hetkeks kõrvalt vaadelda.

Estraadižanri populaarsus oli nõukogude ajal uskumatult suur ning haaras kaasa peaaegu kogu rahvuse (kui mitte enam, arvestades, et samu humoreske esitati kogu Nõukogude Liidus). Selle kõrval tundub Comedy Estonia üsna väikseformaadilise nähtusena. Peamine erinevus peitub ilmselt žanri lisaväärtuses ja vajalikkuses. Tänapäevane komöödia - ühiskonnakriitilisest satiirist lihtsa pilamiseni - pole hädavajadus, vaid meelelahutus. Pühendunud publiku alustalaks on ühtsustunne ja rõõm jagatud naerust (Lockyer \& Myers 2011: 181-182), kuid vajadus seda teha annab lisamõõtme, mille olulisust on raske ülehinnata.

\section{Kokkuvõte}

Eelnev analüüs ja arutelu näitab, mis muudab žanri ligitõmbavaks ja populaarseks: peapõhjus pole mitte teemades, mida komöödia käsitleb, vaid konkreetses kontekstis, milles esinemine toimub. See koosneb nii laiemast (kultuurilisest ja poliitilisest) raamistikust kui ka kitsamalt esineja isiksusest ja/või lavapersoonist. Need tegurid valmistavad publiku ette ja ennustavad mõnel määral ka staatust, mille antud žanr võiks publiku silmis omandada. Püstijalakomöödia eelkäija, estraad, oli väga populaarne 1970. ja 1980. aastatel ning sobitus teksti päritolust hoolimata kohalikku olustikku, olles aluseks intensiivsele dialoogile publikuga, kes janunes võimaluse järele teha ja kuulata sotsiaalset ja poliitilist kriitikat. Tänapäevane Comedy Estonia on paindlik ja üritab alles leida oma joont pärast esimest, kuid nüüdseks juba ammenduvat õnnestumist läbiva teemaga (eesti elu välismaalase pilgu läbi), tuues pubidesse esinema lääne komöödiaartiste ning otsides kohalikke talente avatud mikrofoni õhtutel. Välismaalase vaatepunkt, mida kohalik publik rõõmsa üllatusega tundma õpib, andis Comedy Estonia esinejatele tugeva stardipositsiooni, kuid katsed esineda 
eesti keeles või rääkida eesti sisepoliitikast võivad seda pigem õõnestada kui tugevdada.

Käesolev artikkel püüdis arendada arusaama püstijalakomöödiast ja selle eelkäijatest Eestis, keskendudes žanri populaarsusele ja seda reguleerivate elementide vastasmõjule. Edasiste uurimuste käsitleda jääb detailsem sissevaade esineja ja publiku interaktsiooni Comedy Estonia stand-up õhtutel, eelkõige selle võrdlus eesti- ja ingliskeelsete õhtute puhul. Käesolev uurimus oleks kasu saanud suuremast valikust estraadisketšidest, kuid siiski on põhjust arvata, et nende humoreskide kestva populaarsuse aluseks polnud ainult käsitletavad teemad. Selles protsessis mängisid väga olulist rolli eelkõige poliitiline õhustik, stigmatiseeritud žanr ja marginaliseeritud näitlejapositsioon.

\section{Kommentaar}

1 Artikkel on valminud sihtfinantseeritava teema SF0030181s08 ja grandi ETF 8149 toetusel.

\section{Allikad}

Estraad YouTube'is:

"Kahtlused": http://www.youtube.com/watch?v=rHrzkKkYMDk\&feature=related 28. september 2012.

"Tehnikaajastu": http://www.youtube.com/watch?v=BaalZCfgVO0\&feature=related 28. september 2012.

"Kunstisaalis": http://www.youtube.com/watch?v=H2irYp-dv7M - 28. september 2012.

\section{Kirjandus}

Arusoo, Helen 2001. Estraadiosakond loodi 60 aastat tagasi raha pärast. Intervjuu Rein Klinkiga. Eesti Päevaleht 13. veebruar (http://www.epl.ee/news/melu/estraadiosakondloodi-60-aastat-tagasiraha-parast.d?id=50866375 - 27. september 2012).

Assmann, Jan 2006. Religion and cultural memory. Ten studies. (tlk Livingstone, Rodney) Stanford: Stanford University Press.

Davies, Christie 1990. Ethnic jokes around the world. A comparative analysis. Bloomington: Indiana University Press.

Double, Oliver 2005. Getting the joke: The inner workings of stand-up comedy. London: Methuen. 
Jelavich, Peter 1996. Berlin cabaret [Berliini kabaree]. Cambridge, MA: Harvard University Press.

Kerge, Rainer 2000. Poole tunniga väljavilistamisest ovatsioonideni. Intervjuu Lia Laatsiga. Postimees 12. aprill (http://arhiiv2.postimees.ee:8080/htbin/2art?/leht/00/04/12/uudised.shtmXneljateistkymnes - 27. september 2012).

Koziski, Stephanie 1997. The standup comedian as anthropologist: Intentional culture critics. Boskin, Joseph (toim). The humor prism in 20th century America. Detroit: Wayne State University Press, lk 86-114 (doi:10.1111/j.0022-3840.1984.1802_57.x).

Kulli, Jaanus 2005. Kutse "Meelejahutaja" lindistusele oli defitsiit. Intervjuu Priit Aimlaga. Õhtuleht 8. september (http://www.ohtuleht.ee/180660 - 27. september 2012).

Laks, Tiiu 2009. Ma olen seda naeru nii palju näinud. Intervjuu Eino Baskiniga. Eesti Päevaleht 20. juuni (http://www.epl.ee/news/kultuur/eino-baskin-ma-olen-seda-naerunii-palju-nainud.d?id=51171769 - 27. september 2012).

Lockyer, Sharon \& Myers, Lynn 2011. "It's about expecting the unexpected”: Live standup comedy from the audiences' perspective. Participations: Journal of audience and reception studies $8 \mathrm{nr}$ 2, lk 165-188 (http://www.participations.org/Volume\%208/Issue\%20 2/2c\%20Lockyer\%20Myers.pdf - 28. september 2012).

Lõhmus, Maarja 2012. Political correctness and political humour in Soviet Estonia and beyond. Laineste, Liisi \& Brzozowska, Dorota \& Chłopicki, Władysław (toim) Estonia and Poland. Creativity and tradition in cultural communication 1. Tartu: ELM Scholarly Press, lk 139-158.

Mesropova, Olga 2008. Private space on the public stage: Marriage in Russian stand-up comedy in the 1990s. Mesropova, Olga \& Graham, Seth (toim). Uncensored? Reinventing humor and satire in post-Soviet Russia. Bloomington: Slavica Publishers, lk 219-231.

Mintz, Lawrence E. 1985. Stand-up Comedy as Social and Cultural Mediation. American Quarterly $37 \mathrm{nr}$ 1, lk 71-80 (http://www.asu.edu/courses/fms490bh/total-readings/L-1\%20 Standup\%20Comedy\%20as\%20Social\%20and\%20Cultural\%20Mediation.pdf-28. september 2012).

Möldre, Mari 2010. Eesriie avaneb. Tallinn: Eesti Päevaleht.

Nachman, Gerald 2003. Seriously funny: The rebel comedians of the 1950s and 1960s. New York: Pantheon.

Purcell, Darren \& Brown, Melissa S. \& Gokmen, Mahmut 2010. Achmed the dead terrorist and humour in popular geopolitics. GeoJournal 75, lk 373-385 (http://ou.academia. edu/DarrenPurcell/Papers/84188/Achmed_the_Dead_Terrorist_and_Humor_in_Popular_Geopolitics - 28. september 2012).

Randalu, Ivalo 2001. Vanast filast Aino Himbekiga. Intervjuu Aino Himbekiga. TeaterMuusikaKino märts (http://www.temuki.ee/arhiiv/arhiiv_vana/Muusika/01marts_ $\mathrm{m} 4 . \mathrm{htm}$ - 27. september 2012).

Roosaar, Mart 2012. Eestikeelne stand-up komöödia jõuab Pärnusse. Pärnu Postimees 05.05.2012 (http://www.parnupostimees.ee/830922/com/eestikeelne-stand-up-komoodiajouab-parnusse/ - 28. september 2012). 
Stebbins, Robert A. 1990. The laugh-makers: Stand-up comedy as art, business, and life-style. Montreal and Kingston: McGill-Queen's University Press.

Trilljärv, Aleksander 1919. Lõbus näitelawa: monoloogid, deklamatsioonid, laulud, kupleed, kõned, westelood, soolonumbrid iseloomukujutustest ja mitmesugused naljakad ettekanded. Tallinn: G. Kalla.

Turner Garrison, Laura 2012. The ex-pat revolutionaries of Estonia. Intervjuu Louis Zezeraniga. Splitsider 22. veebruar (http://splitsider.com/2012/02/the-ex-pat-revolutionaries-of-estonia/ - 27. september 2012).

\section{Summary}

\section{Stand-up in Estonia: From Soviet estrada to Comedy Estonia}

\section{Liisi Laineste}

Keywords: estrada, stand-up comedy, audience, "negative exemplar", history of stand-up

The article describes stand-up comedy in Estonia in relation to the local history of the genre. The aim is to cast light upon how the cultural context, but also the performer and audience interaction, works in achieving popularity of comic performance. The figure of a comedian as a "negative exemplar" as described by Lawrence Mintz in 1985, provides an excellent entrance point into discussing the different degrees of status of the genre in both the Soviet period and recent years.

Two periods in Estonian history - totalitarian Soviet time and democratic present time - are under surveillance. During the Soviet period, public shows and recordings of estrada performances were highly valued among the audiences, providing commentary on the shortcomings of the regime and daily life in a seemingly innocent manner. The topics and popularity of the most iconic of these performances are analysed side by side with the repertoire of comedians from Comedy Estonia. The latter, a recent importer of Anglo-American tradition of stand-up in Estonia, also has a devoted audience and established topics, but these differ significantly from the Soviet predecessor, that of estrada. Through a historically situated analysis, it is possible to describe the adoption of traditions (and texts within it) in a meaningful way, so that foreign becomes native and starts functioning as an aspect of collective identity, be it on the level of the entire nation or just a group of fans.

The empirical part of the study presents material from both periods, referring comparatively to some legendary comic texts from the Soviet period and routines of Comedy Estonia comedians. The main focus of the analysis is on the topics and targets that are prevalent in these very distinctive periods and, consequently, on the popularity of the different "stages" of local Estonian stand-up. 